Article

\title{
Cytoprotection of Antioxidant Biocompounds from Grape Pomace: Further Exfoliant Phytoactive Ingredients for Cosmetic Products
}

\author{
Daniela F. Maluf ${ }^{1, *(\mathbb{D}}$, Melissa M. Gonçalves ${ }^{2}$, Rebeca W. O. D'Angelo ${ }^{2}$, Ana B. Girassol ${ }^{1}$, \\ Ana P. Tulio ${ }^{1}$, Yasmine M. Pupo ${ }^{3}$ and Paulo V. Farago ${ }^{4}$ \\ 1 Laboratory of Cosmetic Technology, Department of Pharmacy, Federal University of Parana, \\ 80210-170 Curitiba, PR, Brazil; macadamiaoriental@gmail.com (A.B.G.); anatulio26@hotmail.com (A.P.T.) \\ 2 Postgraduate Program in Pharmaceutical Sciences, Federal University of Parana, 80210-170 Curitiba, PR, \\ Brazil; mmarquesgoncalves@hotmail.com (M.M.G.); rebecawelinski@hotmail.com (R.W.O.D.) \\ 3 Department of Restorative Dentistry, Federal University of Parana, 80210-170 Curitiba, PR, Brazil; \\ yasminemendes@hotmail.com \\ 4 Postgraduate Program in Pharmaceutical Sciences, State University of Ponta Grossa, 84030-900 Ponta Grossa, \\ PR, Brazil; pvfarago@gmail.com \\ * Correspondence: danmaluf@gmail.com or danielamaluf@ufpr.br; Tel.: +55-41-3360-4077
}

Received: 28 June 2018; Accepted: 19 July 2018; Published: 21 July 2018

check for updates

\begin{abstract}
The goal of this study was to investigate the efficacy and the safety of grape pomace (Vitis labrusca L.) obtained from the winemaking process as an antioxidant raw material for cosmetic formulations. Grape pomace was dried and submitted to extraction with solvents. The extracts were filtered and freeze-dried. The extraction carried out with 75\% acetone-water showed a better yield $\left(1.9 \mathrm{~g} \cdot \mathrm{g}^{-1}\right)$. High performance liquid chromatography (HPLC) analysis confirmed the presence of ellagic acid as an active biocompound in the extracts. The Total phenolic content of freeze-dried extracts reached $69.83 \pm 1.02 \mathrm{mg}$ for $75 \%$ acetone-water system. Antioxidant activity determined by the 2,2-Diphenyl-1-picrylhydrazyl (DPPH) method revealed there was no statistical difference between the extract $\left(\mathrm{EC}_{50} 6.9 \pm 0.21\right)$ and butylated hydroxytoluene (BHT) $\left(\mathrm{EC}_{50} 7.6 \pm 0.71\right)$. Results of cytotoxicity showed that extracts from grape pomace were safe, even at the highest concentration tested $\left(200 \mathrm{mg} \cdot \mathrm{mL}^{-1}\right)$ against the 3T3 cell line. Scanning Electron Microscopy (SEM) analysis revealed that there were no morphological cell changes of cells treated. Cytoprotection of cells towards the oxidation promoted by the peroxide solution was observed in the lowest concentration tested $\left(0.73 \mathrm{mg} \cdot \mathrm{mL}^{-1}\right)$. Grape pomace from the winemaking process revealed a significant antioxidant activity attributed to its biocompounds. The safety and efficacy of extracts of grape pomace as raw material for cosmetic formulations was proposed through cell culture assays.
\end{abstract}

Keywords: antioxidant; cell culture; cosmetic ingredient; cytoprotection; ellagic acid; grape marc

\section{Introduction}

The skin consists of an interface between the human body and the environment. Therefore, it is exposed to endogenous and exogenous oxidant agents that could generate many free radicals [1]. Oxidative stress arises when the formation of free radicals is greater than its elimination by the antioxidant defense system of the body. The free radicals damage molecules and cellular structures, which can result in changes to their physiological functions. These processes are among the main causes of skin ageing. Thus, antioxidants are not only employed as preservatives in cosmetic products, preserving the product from decay, but also to protect the skin from damage caused by oxidative 
processes. Interest in the discovery of natural antioxidant agents as total or partial replacements of synthetic antioxidants in which toxicological activities were reported is growing [2-10].

Polyphenols are substances that have more than one phenolic hydroxyl group, bound to one or more benzene ring systems. They are produced in small quantities by the secondary metabolism of plants. Flavonoids are the main group of polyphenols, and include classes such as flavones (quercetin, for example), isoflavones, anthocyanidins, stilbenes (resveratrol), and catechins (epigallocatechin-3-gallate or EGCG) [11-14].

In vitro antioxidant activity is the most common means of evaluating the antioxidant potential of substances in the elimination of free radicals. Inhibition of lipid oxidation plays the protective action of polyphenols in cell membranes. The phenolic content of the extract can be correlated with antioxidant activity, which is often derived from a synergistic effect of active substances. However, the polyphenol extract profile also determines its efficacy, since the individual activity of substances varies widely $[8,15]$.

Many studies have been conducted by isolating and evaluating the activity of phenolic substances in skin cells. Some of them have shown activity against elastase, hyaluronidase, and anti-MMP-1, suggesting that these compounds may exhibit anti-aging effects. Pretreatment of keratinocytes with polyphenols causes a decrease in intracellular ROS formation induced by ultraviolet (UV)B rays. The combination of antioxidants usually present in natural products is more effective due to the synergistic effect produced. Thus, formulations containing more than one antioxidant are superior, due to their synergy effect and to the fact that they protect cells in different layers of the skin [4,16-18].

Grapes have a great number of phenolic compounds in their chemical composition. Grape pomace or grape marc from the winemaking process is also an interesting source of phenolic compounds. Grapes and their bagasse are rich sources of fiber and phenolic compounds and may be considered as a potential source of raw cosmetic materials. The polyphenols from these sources are very promising for the cosmetics industry, which is always in search of new and sustainable sources for active ingredients $[19,20]$. Additionally, grape pomace can be an eco-friendly alternative for cosmetic products, since they can be used as a biodegradable exfoliant ingredient. Synthetic polymeric particles of polyethylene (PE), polypropylene (PP), polymethyl methacrylate (PMMA) and polyethylene terephthalate (PET) are widely employed as exfoliants agents. These microplastics are not removed by conventional water treatment process and can be harmful to the ocean and aquatic environment. Thus, many countries have already banned its use and the cosmetic industry trend needs to employ eco-friendly raw materials such as seed fruits [21,22].

In this context, grape pomace is an example of biodegradable exfoliant with additional antioxidant activity for skin treatments. As an active ingredient in cosmetic products, grape pomace needs to be submitted to safety and efficacy studies. In spite of the well-known exfoliant properties of grape pomace, the literature lacks in evaluating possible cytoprotective effects of the antioxidant biocompounds from this raw material provided by the winemaking process [23]. Therefore, the aim of this study was to assess the antioxidant efficacy and the in vitro safety of the grape pomace of Vitis labrusca L. obtained from winery waste.

\section{Materials and Methods}

\subsection{Plant Material}

The grape pomace of Vitis labrusca L. was obtained from the Franco Italian Winery in Colombo, Paraná, Brazil. After the first press, the pomace was transported to the Federal University of Parana and maintained to $-8^{\circ} \mathrm{C}$ until the drying.

\subsection{Reagents}

Cell culture medium Roswell Park Memorial Institute (RPMI) 1640 and antibiotics (penicillin $100 \mathrm{U} \cdot \mathrm{mL}^{-1}$ / streptomycin $100 \mu \mathrm{g} \cdot \mathrm{mL}^{-1}$ ) were obtained from Sigma (St. Louis, MO, USA). Fetal bovine 
serum was acquired from Gibco Life Technologies (Paisley, UK). 3-(4,5-Dimethylthiazol-2-yl)2,5-Diphenyltetrazolium Bromide (MTT) was purchased from Molecular Probes (Eugene, OR, USA). Extract samples were sterilized by filtering with $0.22 \mu \mathrm{m}$ pore filter membrane (Corning, NY, USA).

\subsection{Extracts Preparation}

The grape pomace was dried at $60^{\circ} \mathrm{C}$ for $2 \mathrm{~h}$. The dry material was then ground in a processor and made into a powder using a mill. Ten grams of dried residue were mixed with $50 \mathrm{~mL}$ of each solvent: acetone, $75 \%$ acetone-water, methanol, $75 \%$ methanol-water, ethanol, and $75 \%$ ethanol-water. Extractions occurred during agitation, for $2 \mathrm{~h}$, at a temperature below $60^{\circ} \mathrm{C}$. After filtration, extracts were freeze-dried in order to calculate yields.

\subsection{High Performance Liquid Chromatography}

Analysis of antioxidant compounds present in freeze-dried extracts was held in gradients, in an HPLC Varian Prostar 420 Autosampler (model 50492, Agilent, Walnut Creek, CA, USA), with a 335, ELO6019048 series Photodiode Array Detector, and a 230/01513 solvent delivery module. Extract sample and standard solutions of quercetin, ellagic acid, and rutin were diluted in methanol $\left(50 \mu \mathrm{g} \cdot \mathrm{mL}^{-1}\right)$. The chromatographic conditions were: a reverse-phase $\mathrm{C} 18$ column; oven temperature of $40^{\circ} \mathrm{C}$; volume of injection of $20 \mu \mathrm{L}$, flow of $0.8 \mathrm{~mL} \cdot \mathrm{min}^{-1}$, running time of $30 \mathrm{~min}$ and mobile phase, as shown in Table 1.

Table 1. High performance liquid chromatography (HPLC) gradient method for antioxidant compound identification in freeze-dried extract of grape pomace.

\begin{tabular}{ccc}
\hline Time (min) & Acidified Water (\%) & Methanol (\%) \\
\hline 0 & 100 & 0 \\
10 & 50 & 50 \\
15 & 40 & 60 \\
20 & 20 & 80 \\
30 & 0 & 100 \\
\hline
\end{tabular}

\subsection{Determination of Total Phenolic Content}

The grape pomace freeze-dried extracts $(0.5 \mathrm{~mL})$ were mixed with distilled water $(8 \mathrm{~mL})$ and the Folin Ciocalteau reagent $(0.5 \mathrm{~mL})$. The solutions were homogenized and then a $20 \%$ sodium carbonate solution $(1 \mathrm{~mL})$ was added. The tubes were stored at room temperature for $1 \mathrm{~h}$ for color development. Absorbance was measured at $720 \mathrm{~nm}$ by the spectrophotometer. Gallic acid was used to calculate the standard curve $\left(2,5,10,15\right.$, and $\left.20 \mathrm{mg} \cdot \mathrm{mL}^{-1}\right)$, and the results were expressed as $\mathrm{mg}$ of gallic acid equivalents (GAE) per g of extract [24].

\subsection{DPPH Radical Scavenging Activity}

Radical scavenging activity was spectrophotometrically evaluated by the DPPH radical method [25]. A methanol solution of lyophilized extract $\left(1 \mathrm{mg} \cdot \mathrm{mL}^{-1}\right)$ was diluted to a range of concentrations ( 0.5 to $25 \mu \mathrm{g} \cdot \mathrm{mL}^{-1}$ ) in 96 -well microplates. The solvent itself was regarded as the control. The DPPH radical scavenging activities of quercetin $\left(0.75\right.$ to $\left.15 \mu \mathrm{g} \cdot \mathrm{mL}^{-1}\right)$ and BHT $(0.11$ to $\left.19 \mu \mathrm{g} \cdot \mathrm{mL}^{-1}\right)$ were also determined for comparison. Aliquots $(200 \mu \mathrm{L})$ of a methanolic solution of DPPH $(0.5 \mathrm{mM})$ were mixed into the wells of the microplate. After $30 \mathrm{~min}$ of incubation, the optical density (OD) was measured at a $518 \mathrm{~nm}$ wavelength using a microplate reader (Thermo Scientific Multiskan ${ }^{\circledR}$ FC, Thermo Fisher Scientific, Vantaa, Finland). DPPH radical scavenging activity was calculated as:

$$
[1-\mathrm{OD}(\mathrm{DPPH}+\text { sample) } / \mathrm{OD}(\mathrm{DPPH} \text { alone })] \times 100 \% .
$$


Experiments were performed in triplicate. For each experiment, the first five concentrations of the DPPH curve were used in order to obtain the equation of straight line $(y=a x+b)$ and so the $\mathrm{EC}_{50}$ was determined by replacing the $\mathrm{y}$ value by 50 to obtain the concentration of the sample with ability to reduce $50 \%$ of DPPH. With results of $\mathrm{EC}_{50}$, the mean and standard deviation were calculated. $\mathrm{EC}_{50}$ was defined as the sufficient concentration to obtain $50 \%$ of the maximum scavenging activity. Statistical analysis was performed by a one-way ANOVA and Tukey post hoc test. Differences were accepted as significant at $p<0.05$.

\subsection{Cell Culture}

The 3 T3 cell line was cultivated in a RPMI culture medium supplemented with $10 \%$ fetal bovine serum (SFB) and $100 \mathrm{U} \cdot \mathrm{mL}^{-1}$ of antibiotic solution (penicillin/streptomycin). Cells were incubated at $37^{\circ} \mathrm{C}$ in a humidified atmosphere with $5 \% \mathrm{CO}_{2}$. Cell growth was monitored daily in an inverted phase microscope, and the culture medium changed every two days. At pre-confluence, cells were harvested using $0.25 \%$ trypsin/ethylenediamine tetraacetic acid (EDTA).

\subsection{MTT Cytotoxicity Assay}

Cells suspended in culture medium were plated in 96-well plates $\left(1.10^{3}\right.$ cells/well). After starvation, culture media supplemented with the extracts $(0.5 ; 1 ; 5 ; 10 ; 20 ; 50 ; 100$, and $200 \mathrm{mg} \cdot \mathrm{mL}^{-1}$ ) were introduced to the cells. Twenty-four hours later, the medium was replaced by the MTT solution $\left(0.05 \mathrm{mg} \cdot \mathrm{mL}^{-1}\right)$ and cells were incubated for $3 \mathrm{~h}$. The MTT solution was removed, and $100 \mathrm{uL}$ of DMSO was added for the solubilization of formazan crystals. Cytotoxicity was assessed by the microplate reader (Thermo Scientific Multiskan ${ }^{\circledR} \mathrm{FC}$, Thermo Fisher Scientific, Vantaa, Finland) at $590 \mathrm{~nm}$ [26]. The optical density (OD) values were converted to \% of cell viability as:

$$
\text { Cell viability } \%=[\mathrm{OD} \text { (treatment) } / \mathrm{OD} \text { (control) }] \times 100 \%
$$

\subsection{Cytoprotection Assay}

Fibroblast cells were plated in a 96-well plate $\left(1 \times 10^{3}\right.$ cells/well). The media was removed $24 \mathrm{~h}$ after seeding (except for the negative control group) and the cells were exposed to an acute dose $(600 \mu \mathrm{M})$ of peroxide $\left(\mathrm{H}_{2} \mathrm{O}_{2}\right)$ in phosphate buffered saline (PBS) (hydrogen peroxide concentration that promoted a 50\% reduction of cell viability) [26]. After this treatment, the solution with the oxidizing agent was removed, and cell viability was then determined by the MTT method.

\subsection{Analysis of Cell Morphology by Scanning Electron Microscopy (SEM)}

3 T3 cells were seeded in a 6-well plate $\left(6 \times 10^{4}\right.$ cells / well $)$ containing sterile coverslips $(13 \mathrm{~mm}$ circular diameter and $0.13 \mathrm{~mm}$ thick) for microscopy. The cells were treated with culture media containing the extracts at the concentrations tested in the cytotoxicity assay. After treatment, cells that remained attached to the coverslips were fixed with $1 \mathrm{~mL}$ of $2.5 \%$ glutaraldehyde solution for $24 \mathrm{~h}$ and dehydrated in several ethanol solutions in concentrations of 30,50,70, 95, and 100\%. Later, the cells were kept in a desiccator for $24 \mathrm{~h}$ for subsequent coating with a thin layer of gold-palladium in a metallizer. Subsequently, they were submitted to Scanning Electron Microscopy through the spectrophotometer (Shimadzu) for evaluation of the morphology of the attached fibroblasts. The micrographs were obtained after visualization of the samples, using voltages of 10 to $15 \mathrm{kV}$ acceleration.

\section{Results}

\subsection{Extracts Preparation}

Extracts from the grape pomace were prepared with six different solvents: acetone, $75 \%$ acetone-water; methanol; 75\% methanol-water; ethanol, and $75 \%$ ethanol-water. 
After freeze-drying, the extracts were weighed to calculate yield. Results were expressed in $\mathrm{mg} \cdot \mathrm{g}^{-1} .75 \%$ acetone-water showed to be more suitable as an extraction solvent (190), followed by $75 \%$ methanol-water (100), acetone (90), ethanol (50), 75\% ethanol-water, and methanol (20).

\subsection{High Performance Liquid Chromatography}

Figure 1 shows the chromatograms of extracts in $75 \%$ acetone-water, $75 \%$ methanol-water, and $75 \%$ ethanol-water. There was no difference observed in chromatographic profile among the solvents tested.

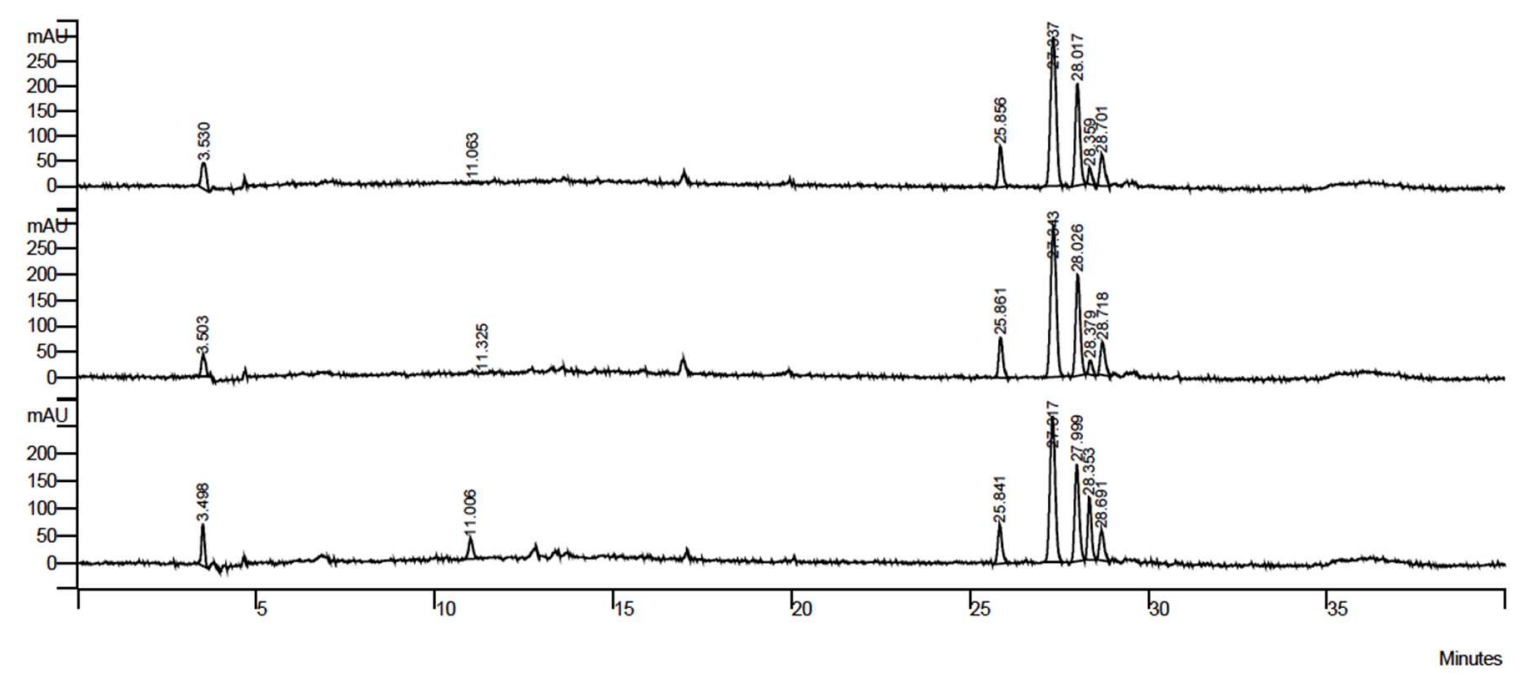

Figure 1. Chromatograms of grape pomace extract in $75 \%$ acetone-water, $75 \%$ methanol-water, and $75 \%$ ethanol-water.

Retention time and UV spectra of the peaks from standard solutions of quercetin, rutin, and ellagic acid were compared with the peaks from the extracts. Of the tested patterns, only ellagic acid was identified by the major peak (at $27 \mathrm{~min}$ ) of the chromatograms of all extracts. Considering the yielded results and the similarity of chromatographic analysis, extracts from $75 \%$ acetone-water were chosen for further assays.

\subsection{Determination of Total Phenolic Content}

The total phenolic content analysis was performed in triplicate by the Folin test. Phenolic compounds were determined through the absorbance values (obtained in milligrams) of gallic acid equivalent (GAE) per gram. The leaching-out value of phenolic compounds reached $69.83 \pm 1.02 \mathrm{mg}$ $\mathrm{GAE} \mathrm{g}^{-1}$ for $75 \%$ acetone-water system; $58.57 \pm 0.37 \mathrm{mg} \mathrm{GAE} \mathrm{g}^{-1}$ for $75 \%$ methanol-water, $56.93 \pm 0.96 \mathrm{mg} \mathrm{GAE} \mathrm{g}^{-1}$ for acetone, $40.16 \pm 1.14 \mathrm{mg} \mathrm{GAE} \mathrm{g}^{-1}$ for ethanol, $35.57 \pm 0.76 \mathrm{mg} \mathrm{GAE} \mathrm{g}^{-1}$ for $75 \%$ ethanol-water, and $35.12 \pm 1.03 \mathrm{mg} \mathrm{GAE} \mathrm{g}^{-1}$ methanol.

\subsection{Antioxidant Effect of Grape Pomace Extract in the DPPH Assay}

Radical scavenging activity of grape pomace extract was compared to quercetin and butylated hydroxytoluene (BHT) by determining their abilities to chemically reduce the stable free DPPH radical (Figure 2).

The sample concentration required to inhibit $50 \%$ of DPPH radical $\left(\mathrm{EC}_{50}\right)$ were used to express the results (Table 2). The smaller this value, the lower the required amount of extract to reduce $50 \%$ of the free DPPH radical becomes, and so the higher its antioxidant capacity. 


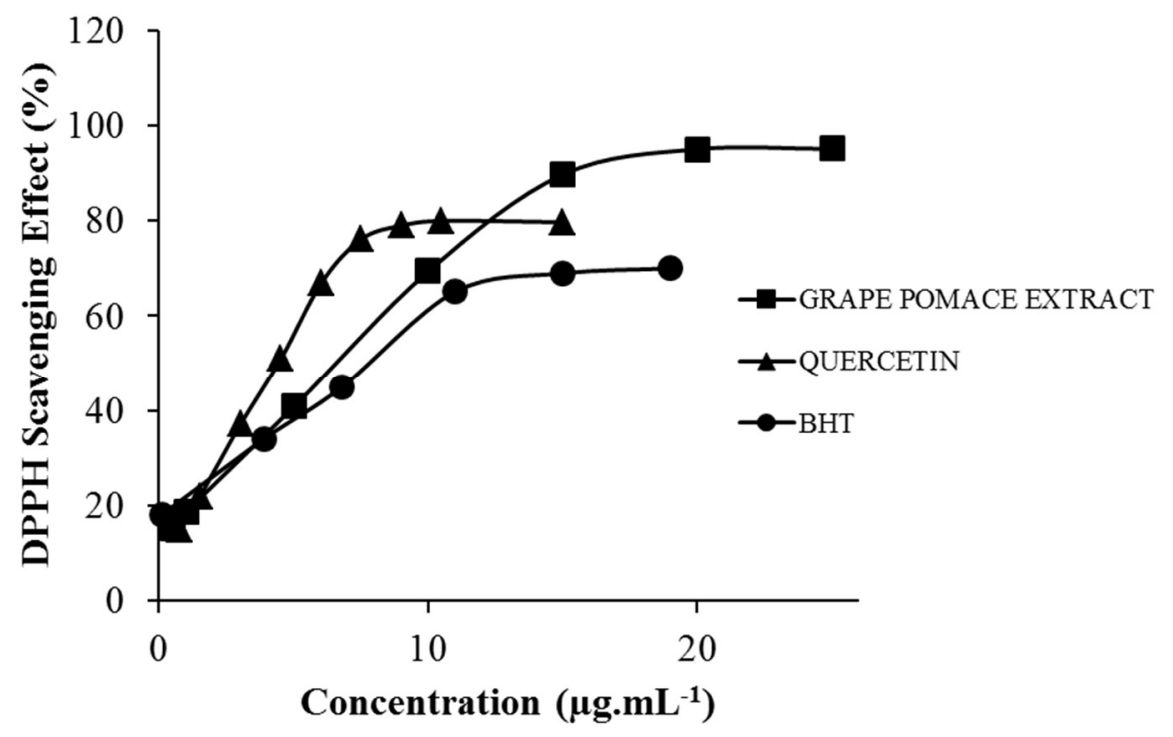

Figure 2. DPPH radical scavenging activity of grape pomace extract isolated by $75 \%$ acetone-water. Quercetin and BHT were used as the positive controls.

Table 2. Effect of grape pomace extract vs. quercetin (natural antioxidant) and BHT (synthetic antioxidant) on DPPH radical-scavenging activity.

\begin{tabular}{ccc}
\hline Antioxidant & Concentration Range $\left(\boldsymbol{\mu g} \cdot \mathbf{m L}^{-\mathbf{1}}\right)$ & $\mathbf{E C}_{\mathbf{5 0}}{ }^{\mathbf{1}}\left(\boldsymbol{\mu g} \cdot \mathbf{m L}^{-\mathbf{1}}\right)$ \\
\hline Grape pomace extract & $0.5-25$ & $6.9 \pm 0.21$ \\
BHT & $0.11-19$ & $7.6 \pm 0.71$ \\
Quercetin & $0.75-15$ & $4.5 \pm 0.35$
\end{tabular}

${ }^{1} \mathrm{EC}_{50}$ effective concentrations have been determined as the concentration leading to $50 \%$ of the maximal DPPH reduction.

\subsection{Cytotoxicity Test}

The analysis of freeze-dried extract of grape pomace by the MTT method revealed that there was no statistically significant difference between the results obtained at the concentrations tested $(0.5 ; 1.0$; $5.0 ; 10.0 ; 50.0 ; 20.0 ; 100.0$, and $200.00 \mathrm{mg} \cdot \mathrm{mL}^{-1}$ ) and the control group (3T3 fibroblast cells treated only with the culture medium), as shown in Figure 3.

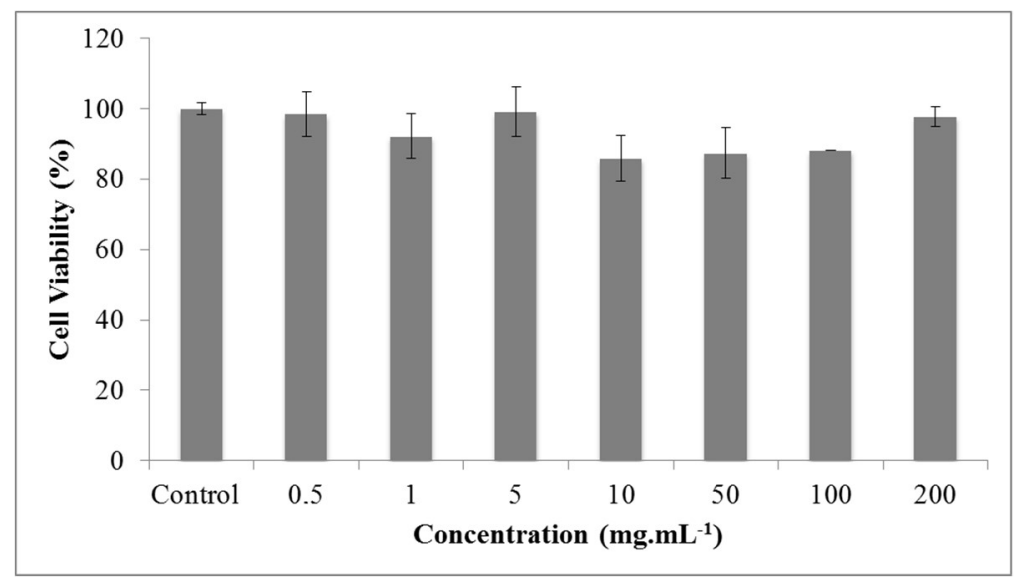

Figure 3. Cell viability $(\%)$ of $3 \mathrm{~T} 3$ cells treated with freeze-dried extract of grape pomace $\left(\mathrm{mg} \cdot \mathrm{mL}^{-1}\right)$ by the MTT assay. Results are expressed as mean \pm SD $(n=5)$. Statistical analysis was performed by a one way ANOVA and Tukey post hoc test. Differences were accepted as significant at $p<0.05$. 


\subsection{Cytoprotection Assay Using $\mathrm{H}_{2} \mathrm{O}_{2}$}

The cytoprotection assay evaluates the antioxidant protection offered to the cells by the lyophilized extract before an acute exposure to $\mathrm{H}_{2} \mathrm{O}_{2}$. A dose-effect relationship was not observed at the concentrations tested. It could eventually occur at a concentration lower than $0.73 \mathrm{mg} \cdot \mathrm{mL}^{-1}$ considering that the DPPH assay revealed a high antioxidant activity of grape pomace at minimum concentrations. The results obtained demonstrate that even at the lowest concentration tested, there was a significant protection of the cells that were treated with freeze-dried extract when compared to the positive control group (cells treated only with $\mathrm{H}_{2} \mathrm{O}_{2} 600 \mu \mathrm{M}$ peroxide solution, see Figure 4).

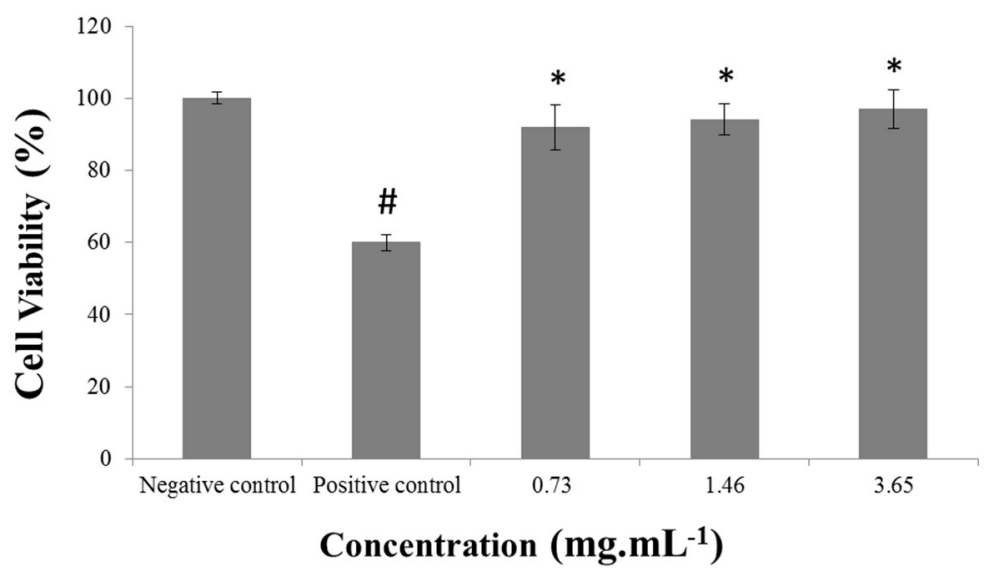

Figure 4. Cell viability (\%) of 3T3 cells treated only with culture medium (negative control), peroxide solution $\mathrm{H}_{2} \mathrm{O}_{2}$ (positive control), and with the freeze-dried extract of grape pomace $\left(\mathrm{mg} \cdot \mathrm{mL}^{-1}\right)$. Results are expressed as mean $\pm \mathrm{SD}(\mathrm{n}=5)$. Statistical analysis was performed by a one way ANOVA and Tukey post hoc test. Differences were accepted as significant at $p<0.01$. $\# p<0.01$ vs. Negative control and ${ }^{*} p<0.01$ vs. Positive control.

\subsection{Analysis of Cell Morphology by Scanning Electron Microscopy}

The analysis of cell morphology by SEM revealed that there were no changes in 3T3 fibroblasts treated with freeze-dried extract of grape pomace. All micrographs showed the spindle shape typical of fibroblasts, with extensions and cytoplasmic projections. The fibroblasts were refractive, which is characteristic of adherent and viable cells. Therefore, no morphological changes were found in the $3 \mathrm{~T} 3$ cell line even with the maximum concentration tested $\left(200 \mathrm{mg} \cdot \mathrm{mL}^{-1}\right)$, when compared to the micrographs of cells treated only with the control group (Figure 5).

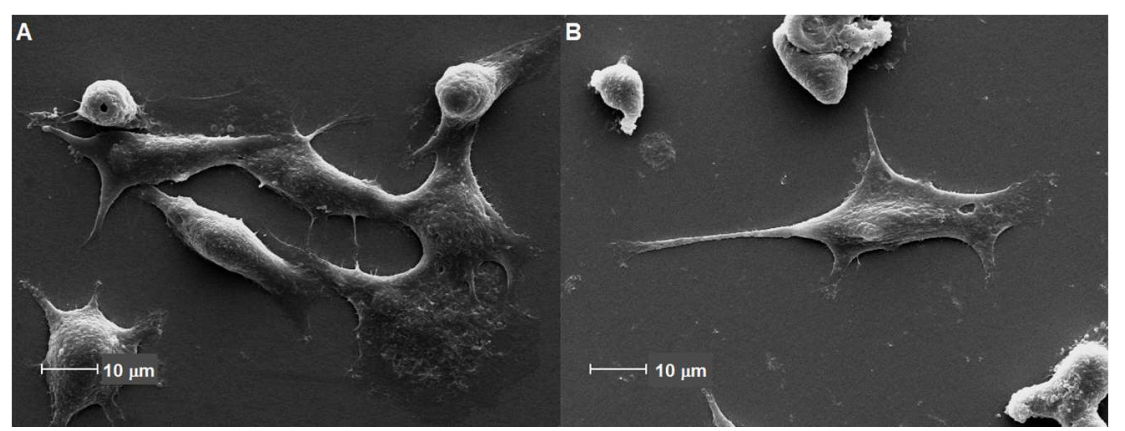

Figure 5. SEM micrographs of 3T3 fibroblasts: (A) Negative control group and (B) Cells treated with freeze-dried extract of grape pomace. The spindle-shaped cells present fine cytoplasmic processes that seem to be keeping the cells attached to the glass substrate. 


\section{Discussion}

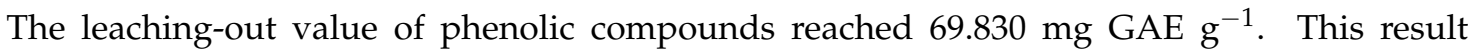
demonstrates a high content of bioactive compounds present in the grape pomace. In addition, this total phenolic content is higher than that reported by Ribeiro et al. (2015), which found $41.245 \mathrm{mg}$ $\mathrm{GAE}^{-1}$ to grape pomace (Vitis labrusca L.) from the winemaking process [27]. The difference in phenolic content can be related to the extract preparation procedure, since these authors used $60 \%$ ethanol-water as solvent, while a 75\% acetone-water was chosen in the present investigation.

Statistical analysis performed by one way ANOVA demonstrated greater antioxidant activity of quercetin when compared to grape pomace extract and BHT. However, there was no statistical difference between the extract and BHT. BHT is a synthetic antioxidant widely used in the cosmetic industry and it is considered safe to use in cosmetic formulations [28], but its toxic effects are well known in the literature [28-30]. The results indicate that the grape pomace extract has a significant DPPH radical scavenging activity and can be proposed as an eco-friendly and biodegradable alternative for BHT. The $\mathrm{EC}_{50}$ obtained $\left(6.9 \pm 0.21 \mu \mathrm{g} \cdot \mathrm{mL}^{-1}\right)$ is also higher than that achieved by Amico et al. (2008) which evaluated the radical scavenging activity of grape pomace (Vitis vinifera L.) extracts from winemaking process and obtained $\mathrm{EC}_{50}$ data between from 9.9 to $30.7 \mu \mathrm{g} \cdot \mathrm{mL}^{-1}$ [31].

These results suggested that grape pomace can be further used as an antioxidant raw material for cosmetics since ellagic acid has demonstrated scavenging activity against a variety of ROS. Its four hydroxyl and two lactone functional groups can act respectively as hydrogen bond acceptors and donors, enabling ellagic acid to scavenge radicals [27].

The grape pomace extract can also be considered safe for skin application. The safety of grape pomace is found in the literature. Melo et al. (2015) investigated the cytoxicity of grape pomace from different grape cultivars against mouse macrophage RAW 264.7 cells and the winery byproduct extracts presented low cytotoxicity [32]. However, this is the first report regarding its evaluation against fibroblast cells in order to make its future skin use feasible. The non-cytotoxic results of grape pomace (Vitis vinifera L.) extract from the winemaking process against 3T3 cell line pave the way for using this exfoliant raw material as a phytoactive antioxidant for cosmetic use.

Cytoprotective activity of fruit and vegetable wastes, including grape pomace, was described by Kabir et al. (2015) in African monkey kidney MA104 cells [33]. Leong et al. (2016) showed the cytoprotective capacity of grape juice (Vitis vinifera L.) against $\mathrm{H}_{2} \mathrm{O}_{2}$-induced oxidative stress in Caco-2 cells [34]. In the present study, grape pomace (Vitis vinifera L.) extract from the winemaking process prevented $\mathrm{H}_{2} \mathrm{O}_{2}$-induced fibroblast cell death. Oxidative stress occurs when cellular homeostasis, which normally involves a fine balance between free radical generation and their detoxification by antioxidants, is disturbed. $\mathrm{H}_{2} \mathrm{O}_{2}$ is well known to act as a potent inducer of reactive oxygen species (ROS) and it is capable of inducing cell injury both in vitro and in vivo. $\mathrm{H}_{2} \mathrm{O}_{2}$ is particularly known to induce oxidative damage, leading to lipid peroxidation, ROS generation, depletion in reduced glutathione, and reduction in antioxidant enzyme activity (catalase, superoxide dismutase, and glutathione peroxidase) preceding cell death [26]. Thus, the cytoprotective effect of grape pomace is a great finding in order to suggest the cosmetic use of this raw material due to its high potential in preventing damages caused in dermal cells such as fibroblasts and preventing skin aging. Further studies are necessary in order to provide a comprehensive solution concerning the development of skin care products based on grape marc.

The cell morphology verified by SEM reinforces the cytoprotective results and demonstrates the potential of grape pomace as feasible raw material for innovative cosmetic application since it also shows an exfoliant effect.

\section{Conclusions}

In the present study, the in vitro efficacy and safety of grape pomace (Vitis labrusca L.) as antioxidant raw material for further cosmetic formulations was proven. Freeze-dried extracts obtained with acetone-water revealed a high total phenolic content and HPLC analysis confirmed the presence 
of ellagic acid as an active biocompound. Antioxidant activity assessed by the DPPH method demonstrated significant antioxidant activity in grape pomace extract when compared to BHT. Results of cytotoxicity and SEM analysis have shown that extracts from grape pomace were safe even in the highest concentration tested. Cytoprotection of fibroblasts treated with freeze-dried extracts from grape pomace was significantly improved. In vitro safety and efficacy tests provided promising results, which revealed that grape pomace can be a potential source of antioxidant raw material for cosmetic purposes.

Author Contributions: D.F.M. designed the study, supervised the experiments, and wrote the manuscript; M.M.G. contributed to the DPPH assay and wrote the manuscript; R.W.O.D. contributed to the DPPH assay and HPLC analysis; A.B.G. contributed to the cell culture and cytotoxicity assay; A.P.T. contributed to the cell culture and cytoprotection assay; Y.M.P. contributed to obtaining of the plant material; P.V.F. contributed to determination of total phenolic content and wrote the discussion section. All the authors have read the final manuscript and approved the submission.

Funding: This research received no external funding.

Acknowledgments: The authors thank the Academic Publishing Advisory Center (Centro de Assessoria de Publicação Acadêmica, CAPA - www.capa.ufpr.br) of the Federal University of Parana for assistance with English language editing.

Conflicts of Interest: The authors declare no conflict of interest.

\section{References}

1. Grazul-Bilska, A.T.; Bilski, J.J.; Redmer, D.A.; Reynolds, L.P.; Abdullah, K.M.; Abdullah, A. Antioxidant capacity of 3D human skin EpiDerm ${ }^{\mathrm{TM}}$ model: Effects of skin moisturizers. Int. J. Cosmet. Sci. 2009, 31, 201-208. [CrossRef] [PubMed]

2. Alonso, A.M.; Guillén, D.A.; Barroso, C.G.; Puertas, B.; García, A. Determination of antioxidant activity of wine byproducts and its correlation with polyphenolic content. J. Agric. Food Chem. 2002, 50, 5832-5836. [CrossRef] [PubMed]

3. Louli, V.; Ragoussis, N.; Magoulas, K. Recovery of phenolic antioxidants from wine industry by products. Bioresour. Technol. 2004, 92, 201-208. [CrossRef] [PubMed]

4. Aranitoyannis, I.; Ladas, D.; Mavromatis, A. Potential uses and applications of treated wine waste: A review. Int. J. Food Sci. Technol. 2006, 41, 475-487. [CrossRef]

5. Rockenbach, I.I.; Rodrigues, E.; Gonzaga, L.V.; Caliari, V.; Genovese, M.I.; Gonçalves, A.E.S.S.; Fett, R. Phenolic compounds content and antioxidant activity in pomace from selected red grapes (Vitis vinifera $\mathrm{L}$. and Vitis labrusca L.) widely produced in Brazil. Food Chem. 2011, 127, 174-179. [CrossRef]

6. Nadim, M.; Auriol, D.; Lamerant-FayeL, N.; Lefèvre, F.; Dubanet, L.; Redziniak, G.; Kieda, C.; Grillon, C. Improvement of polyphenol properties upon glucosylation in a UV-induced skin cell ageing model. Int. J. Cosmet. Sci. 2014, 36, 579-587. [CrossRef] [PubMed]

7. Madeira, J.V., Jr.; Macedo, G.A. Simultaneous Extraction and Biotransformation Process to Obtain High Bioactivity Phenolic Compounds from Brazilian Citrus Residues. Biotechnol. Prog. 2015, 31, 1273-1279. [CrossRef] [PubMed]

8. Zillich, O.V.; Schweiggert-Weisz, U.; Eisner, P.; Kerscher, M. Polyphenols as active ingredients for cosmetic products. Int. J. Cosmet. Sci. 2015, 37, 455-464. [CrossRef] [PubMed]

9. McCook, J.P. Topical Products for the Aging Face. Clin. Plast. Surg. 2016, 43, 597-604. [CrossRef] [PubMed]

10. Tobin, D.J. Introduction to skin aging. J. Tissue Viability 2016, 26, 37-46. [CrossRef] [PubMed]

11. Muñoz-Espada, A.C.; Wood, K.V.; Bordelon, B.; Watkins, B.A. Anthocyanin quantification and radical scavening capacity of Concord, Norton, and Marechal Foch Grapes and wines. J. Agric. Food Chem. 2004, 52, 6779-6786. [CrossRef] [PubMed]

12. Ebrahimi, A.; Schluesener, H. Natural polyphenols against neurodegenerative disorders: Potentials and pitfalls. Ageing Res. Rev. 2012, 11, 329-345. [CrossRef] [PubMed]

13. Tsai, C.C.; Chou, C.H.; Liu, Y.C.; Hsieh, C.W. Ultrasound-assisted extraction of phenolic compounds from Phyllanthus emblica L. and evaluation of antioxidant activities. Int. J. Cosmet. Sci. 2014, 36, 471-476. [CrossRef] [PubMed] 
14. Kammeyer, A.; Luiten, R.M. Oxidation events and skin aging. Ageing Res. Rev. 2015, 21, 16-29. [CrossRef] [PubMed]

15. Vattem, D.A.; Shetty, K. Biological Functionality of Ellagic Acid: A Review. J. Food Biochem. 2005, 29, $234-266$. [CrossRef]

16. Burns, J.; Gardner, P.T.; O’Neil, J.; Crawford, S.; Morecroft, I.; McPhail, D.B.; Lister, C.; Matthews, D.; MacLean, M.R.; Lean, M.E.; et al. Relationship among Antioxidant Activity, Vasodilation Capacity, and Phenolic Content of Red Wines. J. Agric. Food Chem. 2000, 48, 220-230. [CrossRef] [PubMed]

17. Negro, C.; Tomassi, L.; Miceli, A. Phenolic compounds and antioxidant activity from red grape marc extracts. Bioresour. Technol. 2003, 87, 41-44. [CrossRef]

18. González-Paramás, A.M.; Esteban-Ruano, S.; Santos-Buelga, C.; Pascual-Teresa, S.; Rivas-Gonzalo, J.C. Flavonol content and antioxidant activity in winery by products. J. Agric. Food Chem. 2004, 52, $234-248$. [CrossRef] [PubMed]

19. Rivera, D.; Rommi, K.; Fernandes, M.M.; Lantto, R.; Tzanov, T. Biocompounds from rapeseed oil industry co-stream as active ingredients for skin care applications. Int. J. Cosmet. Sci. 2015, 37, 496-505. [CrossRef] [PubMed]

20. Beres, C.; Costa, G.N.S.; Cabezudo, I.; Silva-James, N.K.; Teles, A.S.C.; Cruz, A.P.G.; Mellinger-Silva, C.; Tonon, R.V.; Cabral, L.M.C.; Freitas, S.P. Towards integral utilization of grape pomace from winemaking process: A review. Waste Manag. 2017, 68, 581-594. [CrossRef] [PubMed]

21. Chang, M. Reducing microplastics from facial exfoliating cleansers in wastewater through treatment versus consumer product decisions. Mar. Pollut. Bull. 2015, 101, 330-333. [CrossRef] [PubMed]

22. Napper, I.E.; Bakir, A.; Rowland, S.J.; Thompson, R.C. Characterisation, quantity and sorptive properties of microplastics extracted from cosmetics. Mar. Pollut. Bull. 2015, 99, 178-185. [CrossRef] [PubMed]

23. Soto, M.L.; Falque, E.; Dominguez, H. Relevance of natural phenolics from grape and derivative products in the formulation of cosmetics. Cosmetics 2015, 2, 259-276. [CrossRef]

24. Singleton, V.L.; Rossi, J.A. Colorimetry of total phenolics with phosphomolybdic phosphotungstic acid reagents. Am. J. Enol. Vitic. 1965, 16, 144-158.

25. Brand-Williams, W.; Cuvelier, M.E.; Berset, C. Use of a free radical method to evaluate antioxidant activity. LWT Food Sci. Technol. 1995, 22, 25-30. [CrossRef]

26. Nadal, J.M.; Gomes, M.L.S.; Borsato, D.M.; Almeida, M.A.; Barboza, F.M.; Zawadzki, S.F.; Kanunfre, C.C.; Farago, P.V.; Zanin, S.M.W. Spray-dried Eudragit®L100 microparticles containing ferulic acid: Formulation, in vitro cytoprotection and in vivo anti-platelet effect. Mater. Sci. Eng. C Mater. Biol. Appl. 2016, 64, 318-328. [CrossRef] [PubMed]

27. Ribeiro, L.F.; Ribani, R.H.; Francisco, T.M.G.; Soares, A.A.; Pontarolo, R.; Haminiuk, C.W.I. Profile of bioactive compounds from grape pomace (Vitis vinifera and Vitis labrusca) by spectrophotometric, chromatographic and spectral analyses. J. Chromatogr. B 2015, 1007, 72-80. [CrossRef] [PubMed]

28. Lanigan, R.S.; Yamarik, T.A. Final Report on the Safety Assessment of BHT. Int. J. Toxicol. 2002, 21, 19-94. [CrossRef] [PubMed]

29. Reed, M.; Fujiwara, H.; Thompson, D.C. Comparative metabolism, covalent binding and toxicity of BHT congeners in rat liver slices. Chem. Biol. Interact. 2001, 138, 155-170. [CrossRef]

30. Sun, Y.; Dwyer-Nield, L.D.; Malkinson, A.M.; Zhang, Y.L.; Thompson, J.A. Responses of tumorigenic and non-tumorigenic mouse lung epithelial cell lines to electrophilic metabolites of the tumor promoter butylated hydroxytoluene. Chem. Biol. Interact. 2003, 145, 41-51. [CrossRef]

31. Amico, V.; Chillemi, R.; Mangiafico, S.; Spatafora, C.; Tringali, C. Polyphenol-enriched fractions from Sicilian grape pomace: HPLC-DAD analysis and antioxidant activity. Bioresour. Technol. 2008, 99, 5960-5966. [CrossRef] [PubMed]

32. Melo, P.S.; Massarioli, A.P.; Denny, C.; Santos, L.F.; Franchin, M.; Pereira, G.E.; Vieira, T.M.F.S.; Rosalen, P.L.; Alencar, S.M. Winery by-products: Extraction optimization, phenolic composition and cytotoxic evaluation to act as a new source of scavenging of reactive oxygen species. Food Chem. 2015, 181, 160-169. [CrossRef] [PubMed] 
33. Kabir, F.; Tow, W.W.; Hamauzu, Y.; Katayama, S.; Tanaka, S.; Nakamura, S. Antioxidant and cytoprotective activities of extracts prepared from fruit and vegetable wastes and by-products. Food Chem. 2015, 167, 358-362. [CrossRef] [PubMed]

34. Leong, S.Y.; Burritt, D.J.; Oey, I. Evaluation of the anthocyanin release and health-promoting properties of Pinot Noir grape juices after pulsed electric fields. Food Chem. 2016, 196, 833-841. [CrossRef] [PubMed] 